\title{
The frequency of Factor V G1691A (Leiden) mutation in Iraqi Turks
}

\author{
Irak Türklerinde Faktör V G1691A (Leiden) mutasyon sıklığı
}

\author{
Arjan Esmael, Yonca Eğin, Nejat Akar \\ Department of Pediatric Molecular Genetics, Faculty of Medicine, Ankara University, Ankara, Turkey
}

\section{To the Editor,}

Factor V Leiden (FVL) mutation (G1691A) is a risk factor for the development of venous thromboembolic disorders. Hereditary disorders that predispose to thrombosis include antithrombin, protein C, and protein $\mathrm{S}$ deficiency, as well as such hereditary defects as Factor V G1691A (Leiden) (FVL) and prothrombin G20210A mutation [1,2]. FVL causes activated protein $\mathrm{C}$ resistance and is the most common thrombophilic mutation worldwide [3,4]; however, to the best of our knowledge the frequency of FVL in Iraqi Turks has not been reported.

Iraqi Turks currently live primarily in northern Iraq and are descendants of the Oghuz Turks that originated in Central Asia. The study group included 84 unrelated Iraqi Turks from northern Iraq; 40 from Kirkuk, 20 from Mosul, 10 from Arbil, 10 from Baghdad, and 4 from the Diala and Tikrit regions. Following the receipt of informed consent from all the participants, blood samples were collected into tubes containing EDTA and transferred To the laboratory, and then DNA was extracted from peripheral blood leukocytes according to the phenol-chloroform method. The prevalence of FVL was determined using real-time PCR (RT-PCR), as previously described [5]. In all, 4 (4.8\%) of the 84 participants were diagnosed as FVL carriers and the frequency of FVL was $0.0238 \%$ among Turks living in Iraq. Several studies on FVL mutation in the Turkish population have been published and the prevalences reported ranged from $4 \%$ to $12.2 \%$ [6]. The prevalence of FVL among Turkish Cypriots was reported as $12.2 \%$ versus $7.9 \%$ in Turkey [6,7]. The prevalence of FVL is 3\%-10\% in Europeans, but FVL mutation is rare in East and Southeast Asians [3,4].

The present study's results show that the prevalence of FVL in Iraqi Turks is similar to that in the general Caucasian population.

\section{Acknowledgement}

I am grateful to Professor Nejat Akar, MD and Yonca Eğin for analyzing the samples.

\section{Conflict of interest statement}

The authors of this paper have no conflicts of interest, including specific financial interests, relationships, and/or affiliations relevant to the subject matter or materials included.

\section{References}

1. Bertina RM, Koeleman BP, Koster T, Rosendaal FR, Dirven RJ, de Ronde H, van der Velden PA, Reitsma PH. Mutation in blood coagulation factor $\mathrm{V}$ associated with resistance to activated protein C. Nature 1994;369:64-7. 
2. Poort SR, Rosendaal FR, Reitsma PH, Bertina RM. A common genetic variation in the 3'- untranslated region of the prothrombin gene is associated with elevated plasma prothrombin levels and an increase in venous thrombosis. Blood 1996;88:3698-703.

3. Rees DC, Cox M Clegg JB. World distribution of factor V Leiden. Lancet 1995;346:1133-4.

4. Lucotte G, Mercier G. Population genetics of factor V Leiden in Europe. Blood Cells Mol Dis 2001;27:362-7.
5. Lay MJ, Wittwer CT. Real-time fluorescence genotyping of factor V Leiden during rapid-cycle PCR. Clin Chem 1997;43:2262-7.

6. Akar N. Factor V 1691 G-A mutation distribution in healthy Turkish population. Turk J Hematol 2009;26: 9-11.

7. Akar N, Akar E, Dalgın G, Sozuoz A, Omurlu K, Cin S. Frequency of factor V (1691GA) mutation in Turkish population. Thromb Haemost 1997;78:1527-8. 